book for content and physical quality; the use of guides to recommended books; and book reviews.

Approximately ninety pages are then devoted to the special nature of selecting the following types of materials: free materials; public documents; periodicals; reference works; out-of-print, reprint, microform materials; and non-print materials (thirty pages).

The last half (two hundred pages) presents a series of discussions of various broad subject fields consisting of a description of the fields presented in such a way as to make one basically aware of their general content, the types of materials encountered, and problems and principles of selection unique to each subject field.

The author clearly states that this book is intended for use in introductory first courses on book selection in library schools, and as such it is useful. It is the purpose of an introductory text to present the basic elements of the topic and their interrelationships without involving the student with great amounts of detail. However, the usefulness of a text is greatly enhanced if it includes clear references to recommended supplementary readings from the literature which will carry the reader into the refinements of the subjects and answer any specific questions or desire for additional general information that might arise. The footnotes do not really serve the same function and, given the brevity with which many topics are treated, such a list of recommended readings would be most useful in this book. Broadus gives a brief explanation of the various aspects of publishing and selection, but this serves only as an introduction; details and solutions to problems encountered in their application must be sought elsewhere.

It is also readily apparent that the coverage of topics is sometimes uneven: approval plans are passed over in just sixteen lines; judging the content of a book is given less than one and one-half pages; but eight pages are devoted to quantitative measurement through use and citation studies. One would like to see more about the former, but not less about the latter.
Overall, however, this book does a fine job of imparting the importance of selection by librarians for the properly guided growth of a library's particular collection.-Thomas L. Mann, Northwestern University.

\section{The Development of National Library and}

Information Services: Papers Given at the First Library Association International Workshop, London, 1981. Ed. by Edward Dudley. London: The Library Assn., 1983. 214p. £15. LC 82-240549. ISBN 0-85365-784-X.

The 15 papers included in this book were delivered at the First Library Association International Workshop held in London from August 24 through September 3, 1981. The workshop was structured so that there were "three separate but interrelated seminars," to cover broadly the themes of national library and information service development, the influence of social and technological change on library and information services (LIS), and education in libraries.

According to the editor of the book, Edward Dudley, the workshop attracted "some of Britain's leading practitioners and theorists in major areas of LIS development" to address "problems of some international relevance and then to seek to demonstrate British experience and response to those problems."

The first part of the book (Seminar 1) is concerned primarily with the role and function of national libraries, public libraries, academic and scientific libraries (defined very broadly to include school and special libraries), and bibliographic services in the development of national library and information services. The first paper in the book takes a more generalized view of "the nature of planning in relation to the LIS environment," particularly as it is applied in different political and social contexts.

Seminar 2 addresses the effects of social change and technological change on the provision of library and information services. Also included in this second seminar is a paper on using a systems approach to library planning, and one on the role of low-level technology and mechanized systems, which are more readily available 
to libraries than high-technology systems, in libraries.

Seminar 3 is concerned primarily with the effect on libraries of new developments in learning and teaching, educational policy, and library users in educational institutions. There is also a paper in this part on the development of library and information services in new academic institutions. Except for the final paper, the papers in the third seminar should be of interest to academic librarians because they are concerned exclusively with academic libraries. The final paper, however, belongs more properly in the first seminar because it deals with the national and international provision of interlibrary loan and document delivery, and not at all with education.

There are some problems with the papers that may reduce interest in reading the book. First of all, the speakers used British experience almost exclusively as examples in their presentations. For example, the paper on the role of the public library in national LIS speaks of the development of British public libraries and their present governance, which seems to diverge significantly from practice in American libraries.

Second, it is unfortunate that, although the workshop was held in 1981, this book was not published until 1983. Some of the topics, e.g., technological change and development, in particular, may give a good résumé of activities at the time of the workshop, but subsequent developments have affected its usefulness adversely, and there are now more up-to-date publications available.

Third, each speaker posed a "question for consideration by discussion groups." Each question was related to the topic the speaker had presented and was general enough in nature that the workshop participants could offer concrete solutions and suggestions based on their own experience. Because this was an international workshop, it would have been interesting to have included the conclusions of the group discussions in the book to augment the obvious British bias of the speakers.

One of the primary themes of virtually all the papers is change. Speakers were concerned with planning for change, the effect of social, educational, and technological changes on libraries, the changes in government involvement in libraries, and the changes in financial support for libraries with the then current economic recession.

In addition, several speakers discussed the advantages and disadvantages of centralization versus decentralization of various library and information services at the national level, particularly in terms of the creation and distribution of bibliographic records, the acquisition and interlibrary loaning of material to satisfy user needs, the need for fulfilling national library functions, and the extent of government involvement in libraries.

The need for planning was another prevalent theme of the workshop, particularly in terms of coping with change, anticipating the future, participating in cooperative or national activities, and ensuring greater effectiveness and efficiency at less cost in library and information services.

As Edward Dudley says in the introduction, the "workshop did not seek to come to conclusions ... however, as the papers

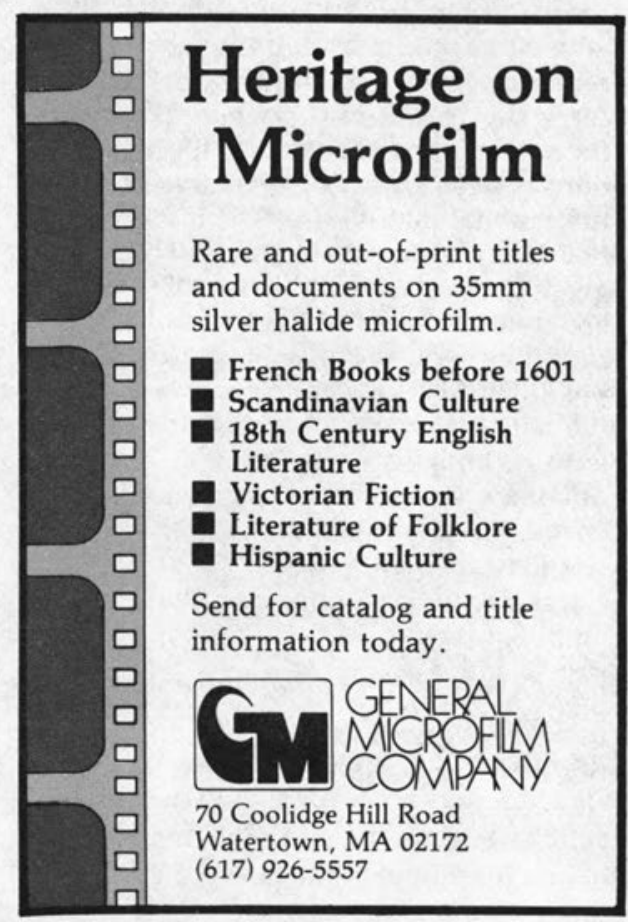


testify, explicitly or implicitly, ... there are problems, questions for agenda papers . . . which are of common, if not universal significance."

In spite of the fact that the book is not prescriptive and does not offer solutions to the problems raised, still it does raise some interesting points for consideration in planning for library and information services on the national level.-Ann Glascoff, Governors State University.

Hyman, Richard Joseph. Shelf Access in Libraries. Chicago: American Library Assn., 1982. 189p. (ALA Studies in Librarianship, no.9) \$12.50. LC 81-22764. ISBN 0-8389-0357-6.

This book is about the past, present, and future of various shelf arrangements in different types of libraries and of direct access to library materials. The major thesis of the book is "that the special shelving schemes in various types of American libraries imply that traditional shelf classification has lost much, sometimes all, of its value." The major schemes, Dewey and LC classifications, are modified in most libraries when it comes to arranging items on the shelves. Typical modifications include shelving by type of book (reference works), by format (microforms and other media), by type of user (children's literature), or by size, among the myriad possibilities. Where there is direct access, shelf arrangement should present users "with worthy selections arranged in suggestive patterns." Since classification schemes are so universally modified in order to facilitate direct access, the author suggests that close classification for the shelves is not worth the time and expense it demands.

Hyman has treated these topics in earlier works; this treatment is long and detailed. The initial chapter traces the evolution of shelf classification and direct access from ancient times through the nineteenth century. Problems and ambiguities of shelf classification receive more elaborate attention in the second chapter. Three subsequent chapters deal with the various shelf arrangements adopted in public libraries, in school libraries and media cen- ters, and in academic and research libraries. The final chapter looks at the future of direct access and includes observations on the future of shelf classification research. The appendix is a reprint of a shelf arrangement used in a public library. Although the arrangement was never fully implemented and was finally abandoned, it serves as an example of shelf arrangement not tied directly to a traditional classification system designed for a catalog.

An ALA press release says that this book aims to help librarians who must decide on when and how to classify for shelf access by readers. If so, it falls short of its mark. The book is really a compendium of relevant studies-many of them classics. The author provides critical commentary, though readers may not always agree with his analyses. The work is highly repetitive and presents no original conclusions. It will be quite useful for students of library science; others in the profession are likely to read it with a certain amount of déjà vu. Nevertheless, there are so many studies included here, that even the seasoned reader will find something new.

Hyman's view of the future of research into shelf classification is not hopeful. One fear he has for research using analysis of electronic access is the potential for invasion of privacy. This reviewer does not believe that analysis of users' reactions to and uses of information necessarily implies a regimented information society. In fact, transaction log analysis offers great potential in identifying patterns of user behavior. The political and social dangers alluded to by the author are avoidable. With the rise of online catalogs, there will be increased opportunities for research. As such catalogs become more sophisticated, we may be able to study more scientifically the phenomenon of browsing - an activity heretofore defended primarily on an intuitive basis. Otherwise, Hyman's assumption may hold up: "The future of direct access is most to be assured because of the human craving for browsing. More than any other factor, this promises the survival of book libraries and shelf-classified collections." -Robert Allen Daugherty, University of Illinois at Chicago. 